Dikumpulkan : 28 Februari 2017

Direvisi : :14 Maret 2017

Diterima : 25 Maret 2017

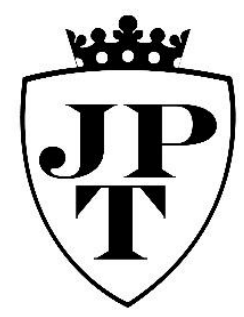

\title{
Pemetaan Wisata Kuliner Khas Kota Surakarta
}

\author{
AMAD SAEROJI, DERIA ADI WIJAYA \\ Diploma III Usaha Perjalanan Wisata, Fakultas Ilmu Budaya, Universitas Sebelas Maret \\ ojie_ahmd@yahoo.com; deriaadi13@gmail.com
}

\begin{abstract}
This article discusses the mapping of specific cuisines as culinary tourism potential in Surakarta. The general objective is to present a culinary-mapping of specific culinary products where the information can be used by stakeholders such as goverment, culinary business, travel industries, including tourists. The implementation of the study has specific objectives: (1) identify the specific culinary potentials in Surakarta, (2) create a culinary tourism map in Surakarta City. This research applies descriptivequalitative research methods in the effort of apprising the information of unique/specific culinary tourism in Surakarta. Data collection techniques wae conducted through participatory observation, indepth interviews and literature studies. The data collection through observation and interviews were conducted in government agencies, travel industries and culinary tourism businesses around Surakarta. The literature study included all concepts and theories related to culinary tourism especially culinary references in Surakarta. The results obtained from this study indicate that the potential of culinary tourism in Surakarta is very diverse with each peculiar identity. In connection with a variety of culinary potential is then presented on the Surakarta culinary map which helps stakeholders in developing Surakarta's culinary tourism.
\end{abstract}

Keywords:

Tourism Maps, Culinary Tourism, Typical Cuisine, Surakarta 


\section{Pendahuluan}

Kota Surakarta sebagai bekas ibukota kerajaan, sangat kaya akan peninggalan-peninggalan yang dapat dijadikan sasaran kunjungan wisata. Kota Surakarta sebagai bekas kota kerajaan Jawa mempunyai peninggalanpeninggalan fisik dan perangkat pranata sosial budaya. Peninggalan-peninggalan tersebut dapat dijadikan sebagai objek wisata (Sutirto, 1995:2). Kota Surakarta atau sering dijuluki Kota Solo adalah kota tujuan wisata budaya di Jawa Tengah kental dengan nuansa budaya Jawa yang masih terjaga hingga saat ini. Surakarta sebagai kota peninggalan Kerajaan Mataram, menyimpan kekayaan potensi alam dan budaya baik fisik maupun nonfisik yang mampu mengangkat citra kota khususnya pada bidang pariwisata.

Sutirto lebih lanjut mendeskripsikan bahwa peninggalan-peninggalan ini tidak saja berwujud peninggalan fisik, seperti gedung-gedung, benda-benda pusaka, senjata dan busana, melainkan juga peninggalan non-fisik yang berupa adatistiadat, tradisi, kesenian, hingga upacara religi. Peninggalan-peninggalan ini apabila dikaitkan dengan masalah kepariwisataan, maka secara garis besar dapat dibedakan menjadi dua, yaitu objek wisata dan atraksi wisata (Sutirto, 1995:26-27).

Kekayaan budaya Kota Surakarta yang memiliki potensi besar untuk dikembangkan dalam kerangka kepariwisataan adalah kuliner. Kuliner kota yang beragam sejatinya belum sepenuhnya dikemas menjadi salah satu atraksi wisata andalan kota. Padahal jika dilihat dari sisi potensi kuliner yang beragam, Surakarta menyimpan referensi kuliner yang lezat yang tersebar di berbagai titik di seluruh penjuru kota dengan masing-masing kuliner khasnya. Kekayaan kuliner tersebut merupakan sebuah modal besar yang harus dimanfaatkan dalam rangka pengembangan daerah dari sisi kepariwisataan.

Perkembangan tren pariwisata dewasa ini yaitu wisata kuliner. Wolf dalam Suriani (2009:12) menjelaskan bahwa "culinary tourism is not prentious for exclusive. Its includes any unique and memorable gastronomic experience, not just restaurant rate four star or better and include both food and all type of beverages". Pernyataan tersebut dapat dimaknai bahwa wisata kuliner bukan hal yang mewah dan esklusif, dan wisata kuliner menekankan pada pengalaman bukan pada kemewahan dari restoran maupun kelengkapan jenis makanan atau minuman yang tersedia.

Fenomena yang dikaji digunakan gagasan atau pemikiran ahli yang relevan di antaranya Suwantoro (2004:48). Suwantoro berpendapat bahwa salah satu ciri produk wisata adalah tidak dapat dipindahkan, tetapi wisatawan yang harus datang jika ingin menikmati produk wisata yang diproduksi, yang kemudian tepat untuk dijadikan dasar pengembangan wisata kuliner. Gagasan tersebut patut diterapkan, mengingat bahwa dalam pengembangan wisata kuliner dengan memanfaatkan bahan baku lokal, manfaat ekonomis harus dinikmati secara langung oleh masyarakat setempat. Dengan demikian, tentu tidak hanya produk wisata kulinernya saja yang diproduksi, namun masyarakatnya juga harus diberikan pembinaan dan pelatihan sehingga mampu menjadi pengolah, penyaji sekaligus sebagai penjual produk wisata kuliner tersebut. John M. Echols (1993) menjelaskan bahwa culinary dapat diartikan sebagai sesuatu yang berhubungan dengan dapur atau masakan. 
Wisata kuliner saat ini menjadi sebuah jenis wisata yang sangat banyak dampaknya bagi perkembangan sebuah daerah (Stowe and Johnston, 2008).

Terdapat beberapa hal yang layak dijadikan pertimbangan dalam menetapkan berbagai macam potensi kuliner khas pada suatu daerah, salah satunya diutarakan oleh Wolf dalam Suriani (2009:13) bahwa beberapa hal yang menjadi pertimbangan atau penilaian wisatawan untuk mengkonsumsi masakan lokal yaitu: a) Harga yang terjangkau; b) Citarasa yang khas; c) Merek (trademark); d) Kemasan lokal; e) Kualitas makanan; f) Porsi yang sesuai harga; g) Lokasi yang autentik; h) Fasilitas fisik bangunan yang khas. Selanjutnya Turgarini dalam Suriani (2009) menambahkan beberapa langkah yang harus dilakukan untuk mengembangkan wisata kuliner lokal, yaitu: a) Inovasi dalam mengembangkan produk berdasarkan sumber daya alam dan sumber daya manusia lokal; b) Ramah lingkungan (sosial dan alam); c) Style atau gaya lokal; d) Keramahtamahan; e) Tetap bertahan pada nilai kelokalan; f) Memiliki keautentikan atau keaslian dari produk wisata kuliner yang tidak terdapat di tempat lain; g) Tetap menjaga kesederhanaan produk kulinernya.

Hadirnya kekayaan kuliner yang terdapat pada suatu kota memiliki daya tarik tersendiri bagi sejumlah wisatawan. Cita rasa yang lezat serta penyajian yang menarik membuat kekhasan pada suatu tempat dimana kuliner tersebut berasal. Pemetaan kuliner tersebut merujuk pada kondisi beragamnya kuliner yang memiliki kekhasan. Surakarta menyimpan kekhasan tersebut yang dapat dijadikan sebagai kekuatan dalam membangun kepariwisataan daerah khususnya pada wisata kuliner.

\section{Metode Lokasi Penelitian}

Penelitian ini berlokasi di Kota Surakarta Provinsi Jawa Tengah Indonesia, dengan area penelitian pada lima kecamatan yakni Kecamatan Banjarsari, Kecamatan Jebres, Kecamatan Serengan, Kecamatan Pasar Kliwon dan Kecamatan Laweyan. Sebab dipilihnya kelima area tersebut dikarenakan masing-masing kecamatan memiliki kuliner yang khas dan beragam sehingga berpotensi untuk menjadikan Kota Surakarta sebagai kota kaya kuliner yang mampu menjadi daya tarik tersendiri bagi wisatawan baik lokal, nasional maupun internasional. Berangkat dari faktor tersebut Kota Surakarta sangat mendukung untuk dijadikan destinasi wisata kuliner dengan pemetaan dari berbagai sajian khas daerah.

\section{Pendekatan}

Penelitian ini berupaya untuk mengidentifikasi potensi-potensi kuliner untuk selanjutnya akan dilakukan penyusunan sebuah peta wisata kuliner khas Kota Surakarta. Mengingat beragamnya kuliner yang tersebar di berbagai tempat maka pendekatan yang tepat adalah pendekatan deskriptifkualitatif dengan mengumpulkan informasi kuliner untuk kemudian diciptakan sebuah paket wisata kuliner.

\section{Teknik Pengumpulan Data}

a. Observasi Partisipasi

Observasi yang dilakukan dalam penelitian ini yakni dengan berpartisipasi langsung di lapangan secara informal dengan mengunjungi beberapa tempattempat kuliner Solo sekaligus melakukan kegiatan wisata kuliner. Mencicipi jenis makanan maupun minuman secara 
langsung di lokasi merupakan kegiatan yang perlu dilakukan guna menikmati kelezatan, keautentikan rasa serta penyajian kuliner yang disuguhkan pada pusat-pusat kuliner yang tersebar di seputaran Kota Surakarta. selain itu dengan kegiatan observasi langsung dan partisipatif ini sekaligus dapat memperkuat analisis dalam mendeskripsikan beragam potensi kuliner khas Kota Surakarta.

b. Wawancara Mendalam

Wawancara yang dilakukan dalam penelitian ini menggunakan teknik in-depth interview. Wawancara dilakukan secara langsung terhadap informan seperti pemilik warung, karyawan, maupun pembeli atas pertimbangan bahwa informan tersebut berkompeten untuk menjawab permasalahan bidang penelitian. Wawancara dilakukan sesaat setelah maupun ketika observasi lapangan secara informal dan tidak ada terencana. Wawancara memberi kesempatan pewawancara untuk mengetahui segala sesuatu di balik tingkah laku seseorang. Dengan wawancara motif, respon emosional, dan proses-proses sosial pada pengalaman manusia dan keadaan sosial yang terdapat di sekitarnya dapat diketahui (H.B. Sutopo, 1992: 2; Koentjoroningrat dan Donal K. Emmorson, 1982: 227).

\section{c. Studi Pustaka}

Studi pustaka yang dilakukan berupa mengumpulkan referensi-referensi terkait yang bersumber dari buku, jurnal, maupun karya tulis lainnya yang terdapat pada perpustakaan Laboratorium Tour Fakultas IImu Budaya maupun perpusatakaan pusat Universitas Sebelas Maret Surakarta. Selain itu sumber-sumber dokumen pemerintah seperti dokumen Dinas Pariwisata Kota Surakarta dibutuhkan untuk memetakan wisata kuliner yang ada beserta
perkembangannya.

\section{Validitas Data}

Validasi data menggunakan "trianggulasi multi side". Berbagai data yang diperoleh selalu dibandingkan dan diuji dengan data yang lain, sehingga data tersebut dapat saling melengkapi. Validitas semacam ini disebut validitas internal untuk memperoleh "the truth value". Penggunaan validasi semacam ini hasil penelitian dapat dipercaya atau mempunyai kredibilitas (S. Nasution, 1996: 10; HB. Sutopo, 1992: 9-10).

\section{Teknik Analisis}

Penelitian ini digunakan teknik analisis model interaktif melalui komponen pengumpulan data, reduksi data, sajian data, dan (penarikan kesimpulan atau verifiksi). Komponen-komponen tersebut terlibat dalam proses dan saling berkaitan serta menentukan hasil akhir analisis. Sebagai penjelasan mekanisme analisis yang mencerminkan keterkaitan antar tahapan dikenal sebagai Skema Model Analisis Interaktif (Miles dan Huberman, 1992).

\section{Hasil dan Pembahasan \\ Gambaran Umum Kota Surakarta}

Surakarta merupakan kota metropolitan yang didukung oleh 6 (enam) wilayah hinterland yang dikenal dengan nama "Soloraya" atau Kawasan "SUBOSUKAWONOSRATEN" (Surakarta, Boyolali, Sukoharjo, Karanganyar, Wonogiri, Sragen, dan Klaten). Dalam area kerjasama antar tujuh wilayah ini, Kota Surakarta menjadi hub bagi daerah hinterland-nya. Kota Surakarta merupakan pusat pertumbuhan di wilayah Jawa Tengah bagian selatan, yang memiliki 
potensi ekonomi yang sangat tinggi, khususnya di bidang industri, perdagangan, dan pariwisata.

Kota Surakarta secara administratif terbagi dalam lima kecamatan yakni Kecamatan Laweyan terdiri dari 11 kelurahan, Kecamatan Serengan terdiri dari 7 kelurahan, Kecamatan Pasar Kliwon terdiri dari 9 kelurahan, Kecamatan Jebres terdiri dari 11 kelurahan dan Kecamatan Banjarsari terdiri dari 13 kelurahan.

Keberadaan posisi Kota Surakarta sangat strategis, yaitu pada pertemuan jalur Pantura (Semarang) dan jalur pesisir selatan Jawa (Yogyakarta), memungkinkan kota ini menjadi tempat transit serta tempat kunjungan wisatawan dari luar Kota Surakarta. Selain itu Kota Surakarta juga ditunjang oleh keberagaman potensi wisata yang cukup menarik, antara lain: wisata heritage (cagar budaya dan nilai-nilai tradisional), wisata sejarah, wisata belanja, serta wisata kuliner.

Secara umum kawasan peruntukan pariwisata di Kota Surakarta tersebar diantara lima kecamatan, yaitu: (1) Kawasan wisata cagar budaya, sejarah, dan nilai-nilai tradisional terletak di Kecamatan Laweyan, Kecamatan Banjarsari, dan Kecamatan Pasar Kliwon; (2) Kawasan wisata belanja meliputi wisata belanja batik dan wisata belanja barang antik. Kawasan wisata belanja batik berada di Kecamatan Pasar Kliwon dan Kecamatan Laweyan; dan wisata barang antik berada di Kecamatan Banjarsari dan Kecamatan Pasar Kliwon; (4) sedangkan kawasan wisata kuliner lokasinya tersebar di seluruh wilayah kota.

\section{Identifikasi Potensi Wisata Kuliner Kota Surakarta}

Kota Surakarta memiliki berbagai macam potensi wisata, mulai dari budaya, sejarah, wisata belanja, serta wisata kulinernya. Potensi tersebut apabila dikembangkan secara maksimal maka dapat menjadi magnet penarik wisatawan untuk berkunjung ke Kota Surakarta. Kota Surakarta juga terkenal dengan julukan Kota Keplek Ilat, artinya kota ini terkenal dengan berbagai jenis masakan kuliner khas yang dapat memanjakan lidah para penggemar makanan.

Berdasarkan preferensi para peneliti ditambah beberapa masukan dari Focus Group Discussion (FGD) yang digelar dengan melibatkan unsur pemerintah, akademisi, budayawan, pelaku usaha dan pemerhati wisata kuliner Kota Surakarta, maka muncul beberapa ikon kuliner yang dirasa dapat dikembangkan menjadi obyek daya tarik wisata kuliner di Surakarta. Beberapa kuliner tersebut ialah:

\section{a. Gudeg Ceker}

Seperti pada umumnya masakan gudeg terbuat dari nangka muda, namun yang berbeda ialah gudeg ini dihidangkan bersama dengan masakan pendamping yaitu ceker (kaki ayam). Ceker ayam tersebut dimasak dengan cara direbus dengan santan, sehingga terasa lunak dan gurih. Perpaduan antara gudeg dan ceker tersebut terasa nikmat dengan ditambahkan sambal goreng krecek yang terbuat dari kerupuk kulit sapi. Gudeg ceker dimakan dengan nasi atau bubur kemudian disajikan dengan kuah areh (semacam bubur gurih dari kelapa) ayam kampung, telur, atau tahu. Gudeg ceker ini dapat ditemukan di Warung Gudeg Ceker Bu Kasno yang beralamatkan di Jalan Wolter Monginsidi, Margoyudan, Banjarsari, Surakarta. Warung ini biasanya buka dari jam 02.00 dini hari hingga jam 07.00 WIB, dengan harga 20.000 rupiah per porsi. 
Selain itu kuliner tersebut juga tersedia di Restoran "Adem Ayem" yang beralamatkan di Jalan Brigjen Slamet Riyadi No.271, Penumping Laweyan Surakarta, serta dapat pula dijumpai di Rumah Makan "Gudeg Ayu" di Jalan Gajah Mada No. 152 Ketelan Banjarsari Surakarta, dan di Jalan Dr. Moewardi No.33 Purwosari Laweyan Surakarta.

\section{b. Tengkleng Kambing}

Tengkleng kambing merupakan salah satu kuliner khas Kota Surakarta, karena tidak ditemukan di daerah lain. Sejarah terciptanya masakan ini dimulai ketika jaman pendudukan Belanda di Kota Surakarta. Mahalnya daging kambing di masa itu, maka hanya para pembesar Belanda dan orang-orang Eropa yang dapat menikmati daging kambing sedangkan tulang-tulangnya dibuang. Bagi para pribumi yang tidak mampu membeli daging kambing, mereka mencoba memanfaatkan sisa-sisa tulang kambing untuk dimasak dengan bumbu-bumbu sederhana lalu tercipta masakan tengkleng ini. Meskipun hanya tulang, biasanya masih ada sedikit daging yang menempel pada sisi tulangtulang tersebut. Tengkleng Sampai sekarang pun yang dijual kebanyakan hanya menyuguhkan tulang dan jerohan kambing dengan sedikit daging, namun biasanya sudah ditambah dengan jeroan dari kambing.

Tengkleng adalah masakan sejenis sup dengan bahan utama kepala, kaki, dan tulang kambing. Bentuk fisik dari dari Tengkleng berbeda dengan gulai kambing, terutama pada kuahnya, bila gulai kental maka tengkleng kuahnya encer. Rasa kuah tengkleng kambing ini gurih, asam, manis, asin karena berasal dari campuran berbagai bumbu seperti lengkuas, serai, kemiri, kunyit, bawang merah, bawang putih, daun salam, dan ketumbar.

Makanan ini biasanya dapat ditemukan di warung Bu Jito Dlidir dengan alamat Jalan Kolonel Sugiono No. 67, Banjarsari, Surakarta. Warung ini biasa melayani pembeli pada jam 09.00-21.00 dengan harga 20.000 rupiah per porsi. Selain itu masakan ini dapat pula ditemukan di Komplek Pasar Buah Pasar Gedhe, lantai 2, Jebres, Surakarta. Selain itu Tengkleng Kambing khas Kota Surakarta ini juga terdapat pada Warung Tengkleng Bu Edi yang dahulu berada di bawah Gapura Pasar Klewer, namun semenjak terjadi kebakaran di Pasar Klewer di tahun 2014, lokasi Warung Tengkleng Bu Edi berada di sebelah selatan lahan parkir Masjid Agung Kota Surakarta.

\section{c. Nasi Liwet}

Nasi Liwet merupakan salah satu kuliner khas Kota Surakarta yang terkenal. Nasi Liwet adalah nasi gurih (dimasak dengan kelapa) mirip nasi uduk, yang disajikan dengan sayur labu siam, opor suwiran ayam (daging ayam dipotong kecilkecil) dan areh. Cara penyajian dari Nasi Liwet ini cukup unik dengan menggunakan pincuk (daun pisang) sebagai tempat makannya. Nasi Liwet ini tersedia di rumah makan Nasi Liwet Bu Wongso Lemu, yang berlokasi di Jalan Teuku Umar, Keprabon, Banjarsari, Surakarta. Jam buka mulai pukul 16.00 sampai 01.00 WIB, dengan harga 15.000 rupiah per porsi.

\section{d. Timlo Solo}

Timlo Solo adalah masakan berkuah bening yang terdiri, sosis Solo yang dipotong-potong, telur ayam pindang, dan irisan ati ampela ayam. Masakan ini biasanya disantap dengan nasi putih yang ditaburi bawang goreng. Rasa masakan ini 
hampir mirip dengan soto, perbedaannya Timlo tidak menggunakan sayuran, dan bahan yang hanya bisa ditemui didalam Timlo adalah potongan dari Sosis Solo (sejenis lumpia dengan isi daging ayam cincang).

Masakan ini dapat ditemukan di Restoran Timlo Solo yang beralamatkan Jalan Urip Sumoharjo timur Pasar Gedhe Surakarta, dengan jam operasional dari 09.00-21.00 WIB, dengan harga 18.000 rupiah per-porsi. Timlo Solo juga tersedia di Warung Timlo Sastro, Keprabon, Banjarsari, Surakarta. Selain itu salah satu kuliner khas Kota Surakarta ini juga dapat dinikmati di Warung Timlo Sastro yang berada di Jalan Pasar Gedhe Timur No. 1-2 Sudiroprajan, Jebres Surakarta tepatnya di timur Pasar Gedhe Harjonagoro, serta di Warung Timlo Maestro yang berlokasi di Jalan Ahmad Dahlan No. 60 Keprabon Banjarsari, Surakarta.

\section{e.Sate Kere}

Sate Kere adalah salah satu ikon kuliner dari Solo. Sate 'kere' (miskin) disebut-sebut lahir karena dulunya sate daging dianggap makanan mewah yang hanya disantap kalangan menengah ke atas. Akhirnya masyarakat miskin atau 'kere' membuat sate versi lain dengan menggunakan tempe 'gembus' (ampas tahu) atau jeroan sapi. Jerohan sapi yang digunakan adalah kikil, limpa, hati, dan lainlain. Sedangkan yang paling terkenal dari Sate Kere adalah tempe gembus. Kita bisa membeli dan bebas memilih sate apapun, kemudian dibakar dan disajikan dengan lontong. Penjual Sate Kere terkenal di Surakarta adalah Sate Kere Yu Rebi, yang beralamatkan di Jalan Kebangkitan Nasional No. 1-2, Laweyan, Surakarta. Jam buka Sate Kere Yu Rebi buka dari jam 10.0021.00 WIB. Sate Gembus kita dapat membeli dengan harga 1.000 rupiah per tusuk, dan untuk jerohan kita perlu membayar 1.500 rupiah per tusuk.

\section{f. Sate Buntel}

Sate Buntel adalah jenis masakan sate yang terbuat dari daging kambing. Keunikan dari jenis masakan sate ini ialah terbuat dari daging kambing yang dicincang halus, dibumbui dengan bawang dan merica kemudian dibungkus (dibuntel) dengan lemak kambing. Biasanya masakan ini disantap bersama dengan kecap, irisan cabe rawit, bawang merah, irisan kol dan tomat. Sate Buntel ini tersedia di Warung Sate Pak Narto, Jalan Kyai Mojo, Baturono, Pasar Kliwon atau di Warung Sate Haji Bejo, Jalan Sebakung No. 10, Loji Wetan, Pasar Kliwon Surakarta. Namun ada satu penjual Sate Buntel yang paling terkenal yaitu di Warung Sate Tambak Segaran yang berlokasi di jalan Tambaksegaran (Sutan Syahrir) No. 39, Banjarsari, Surakarta. Warung tersebut buka dari jam 06.00 hingga pukul 16.00 WIB. Satu porsi Sate Buntel kambing ditawarkan dengan harga 35.000 rupiah. Selain itu, penjual Sate Buntel yang cukup terkenal lainnya ialah Warung Sate Mbok Galak yang berada di J. Mangun Sarkoro No. 122 Banyuanyar Banjarsari Surakarta. Selain terkenal memiliki citarasanya yang khas, saat ini warung sate ini menjadi semakin terkenal karena merupakan salah satu tempat makan favorit dari Presiden Joko Widodo di Kota Surakarta.

g. Pecel Ndeso

Pecel Ndeso adalah masakan yang mirip nasi pecel pada umumnya, letak perbedaannya adalah pada sambal pecel yang menggunakan campuran bahan cabuk, yaitu ampas dari proses pembuatan minyak wijen. Campuran dari bahan cabuk inilah yang memberikan warna hitam pada 
sajian sambal Pecel Ndeso ini. Pecel Ndeso ini biasanya disajikan di atas pincuk yang terbuat dari daun pisang yang menambah kesan tradisional. Sajian Pecel Ndeso terdiri dari seporsi nasi merah yang disajikan dengan sayuran yang direbus seperti daun bayam, daun singkong, daun pepaya, kacang panjang, kembang turi, kecipir, kecambah, petai Cina (melanding) kemudian disiram dengan sambal pecel bertekstur kental dan berwarna hitam. Untuk menambah aroma ditambahkan daun kemangi segar dan juga potongan mentimun yang menambah kesegaran. Tidak lupa ditambah dengan karak (olahan kerupuk dari bahan beras) yang menambah rasa gurih dan renyah. Sebagai tambahan lauk-pauknya, disajikan bongko dan gembrot. Bongko merupakan sejenis pepes kacang tholo (merah) yang dicampur dengan parutan kelapa. Sedangkan gembrot sejenis pepes yang terbuat dari daun sembukan yang dicampur dengan parutan kelapa. Kedua sajian masakan ini memiliki cita rasa manis dan gurih, sangat pas disajikan bersama dengan Pecel Ndeso.

Untuk dapat menikmati kuliner Pecel Ndeso bisa dijumpai di Rumah Makan Pecel Solo yang beralamatkan di Jalan Dr. Supomo No. 55 Turisari Banjarsari Surakarta. Namun jika ingin menikmati dengan suasana yang 'merakyat' maka penjual kuliner ini biasa berjualan di area Pasar Gedhe Harjonagoro Jebres Surakarta, tepatnya disebelah kiri pintu masuk utama pasar Walaupun gelaran lapaknya nampak sederhana dan terlihat apa adanya, namun jangan ragukan cita rasanya sajiannya. Harga dari Pecel Ndeso ini sangat terjangkau, untuk satu pincuk termasuk lauknya hanya 10.000 rupiah, penjual Pecel Ndeso ini mulai melayani pembeli dari jam 06.00 hingga 10.00 WIB. selain itu penjual Pecel Ndeso ini dapat pula dijumpai di Shelter sebelah utara Stadion Manahan Surakarta.

h. Bestik Solo

Bestik merupakan makanan khas Solo yang memiliki cita rasa nikmat. Bestik bisa diidentikan mengacu pada Steak, namun dalam penyajiannya disesuaikan dengan selera dan bahan-bahan lokal sehingga menjadi sebuah makanan khas yang mengadopsi budaya non-lokal dengan budaya lokal. Bahan utama yang digunakan berupa daging/lidah sapi dan dicampur dengan tomat, wortel, kentang, sawi, bawang bombay, selada dengan kuah manis yang berwarna kecoklatan. Kenikmatan tidak hanya pada dagingnya, melainkan pada kuahnya yang segar dan gurih.

Warung Bestik yang cukup populer di Solo adalah Warung Harjo Bestik yang beralamatkan di Jalan Dr. Radjiman timur perempatan Pasar Kembang Kemlayan Serengan, Surakarta, atau dapat pula dibeli di Warung Bestik Pak Darmo yang berada di Jalan Honggowongso No. 94 Panularan Laweyan Surakarta. Selain itu, penjual Bestik Solo yang tidak kalah terkenal ialah Bestik Pak Mangun, yang berlokasi di Jalan Perintis Kemerdekaan No. 77, Kabangan Kecamatan Laweyan. Jam buka Warung Bestik Pak Mangun mulai pukul 16.00 sampai 22.00. Walaupun hanya berupa warung kaki lima dan tidak cukup luas namun Warung Bestik Pak Mangun selalu ramai penikmat kuliner Bestik baik dari kalangan menengah maupun dari kalangan menengah atas. Harga untuk satu porsi kurang lebih 20.000 rupiah (Wawancara dengan Bu Sri, penjual Bestik Pak Mangun tanggal 22 April 2016).

i. Selat Solo 
Selat Solo adalah makanan khas Kota Surakarta yang merupakan warisan dari jaman pendudukan bangsa Belanda. Kata 'selat' diadopsi dari bahasa Belanda 'slachtje' yang artinya hasil penyembelihan daging yang dijadikan kecil-kecil. Namun kala itu lidah orang pribumi susah menyebut kata slachtje lantas mereka sering mengucapkannya dengan kata 'selat'. Awal mula lahirnya masakan ini berawal sejak benteng Vastenburg dibangun, tepat di depan gapura keraton Surakarta, sering terjadi pertemuan dan rapat antara pihak keraton dan pihak Belanda. Setiap pertemuan itu pasti disediakan makanan namun tidak sesuai dengan selera masyarakat Belanda yang menginginkan makanan berbahan utama daging, sedangkan sang raja terbiasa dengan sajian sayur. Maka keluhan dari kedua pihak tersebut di tindaklanjuti dengan menciptakan menu baru dengan mengkombinasikan bahan-bahan seperti aardappel (kentang), wortelen (wortel), boon (buncis), komkommer (ketimun), sla (slada), ei (telur), dan sojasous (kuah kecap), serta saus mayones. Kemudian dari pertemuan dua kebudayaan tersebut melahirkan satu kuliner khas dari Kota Surakarta.

Penjual masakan Selat Solo yang paling terkenal ialah Warung Selat Mbak Lies. Meskipun berada di tengah perkampungan warga, warung selat yang beralamatkan di Kampung Serengan 2 No. 42, RT03/RWo2 ini tidak pernah sepi dari pengunjung. Warung Selat Mbak Lies ini buka dari jam 08.00 hingga 17.00 WIB, dengan kisaran harga 15.000 rupiah per porsi. Selain itu jenis kuliner khas Kota Surakarta ini juga dapat ditemukan di Rumah Makan Selat Vien's Solo yang berada di jalan Hasanuddin No. 99, Banjarsari Surakarta, atau dapat pula dinikmati di Restoran Kusuma Sari dengan alamat Jl. Yos Sudarso No. 81 Kemlayan, Serengan Surakarta.

\section{j. Soto Gading}

Soto Gading adalah kuliner yang cukup populer di Kota Surakarta yang berlokasi di daerah Gading kecamatan Pasar Kliwon. Pada dasarnya Soto Gading merupakan soto ayam, sedangkan Gading adalah nama daerah dimana soto tersebut berasal. Jika dilihat dari namanya sudah cukup legendaris, namun dari sisi kekhasannya Soto Gading memiliki kuah bening yang ringan karena rempahnya tidak begitu kuat. Kaldunya yang sangat terasa dengan isi berupa soon serta suwiran daging ayam dapat memanjakan lidah penikmatnya. Aneka panganan pendamping disajikan secara terpisah seperti tahu, tempe, sate usus, sate daging sapi, empal atau perkedel juga turut menambah cita rasa tersendiri. Selain itu dapat lebih nikmat lagi jika disajikan dengan minuman wedang/es beras kencur.

Warung Soto Gading beralamatkan di Jalan Brigjen Sudiarto No. 75 Gading, Pasar Kliwon dan dibuka dari pagi jam 6.00 WIB sampai sore hari. Harga untuk satu porsi Soto relatif murah yakni 7.000 rupiah, di luar harga aneka penganan pendamping. Warung soto tersebut tidak hanya dikunjungi masyarakat kalangan bawah saja melainkan para pejabat negara pun pernah mencicipi soto tersebut (wawancara dengan Ani, pelayan warung tanggal 26 April 2015).

\section{k. Kue Mandarijn}

Salah satu kuliner khas yang menjadi ikon kuliner di Kota Surakarta ialah kue Mandarijn yang dijual di Toko Roti Orion. Toko Roti Orion telah ada sejak 23 Maret 1932, yang didirikan oleh Njoo Hong 
Yauw dan istrinya Tjan Giok Nio di masa pemerintahan Hindia-Belanda. Sedangkan nama kue "Mandarijn" sebagai kue andalan toko roti ini diambil dari bahasa Belanda yang artinya 'Priyayi Cina'.

Kue Mandarijn merupakan kue basah dengan dua sisi roti warna coklat dan warna kuning yang bertumpuk dengan dilapisi selai nanas. Harum aromanya yang khas, legit, serta teksturnya yang lembut menjadi identitas dari kue Mandarijn buatan Toko Orion, dimana hal tersebut menjadi perbedaan dengan kue lapis khas Surabaya yang mungkin sekilas akan terlihat sama. Kue Mandarijn tersedia di Toko Roti Orion ini memiliki tiga macam varian, yaitu Mandarijn biasa, Mandarijn spesial, dan Mandarijn kismis. Perbedaan antara kue Mandarijn biasa dan spesial terletak pada penggunaan mentega. Mandarijn biasa hanya memakai mentega, sedangkan Mandarijn spesial menggunakan roombutter yang wanginya cukup kuat. Sementara kue Mandarijn kismis adalah kue Mandarijn biasa yang ditaburi kismis sampai ke bagian dalam kue.

Semua kue Mandarijn ini dikemas dalam box dengan dua ukuran, yaitu ukuran kecil $(16 \times 18 \mathrm{~cm})$ dan ukuran besar $(28 \times 30 \mathrm{~cm})$ dengan harga berkisar mulai Rp. 52.500,- hingga Rp.115.000,-. Lokasi Toko Roti Orion hanya berada di Jalan Urip Sumoharjo No. 80 yaitu tepatnya di sebelah utara Pasar Gedhe Harjonagoro dan tidak membuka cabang di daerah atau kota lain. Sampai saat ini, roti Mandarijn buatan Toko Roti Orion selalu menjadi oleh-oleh wajib bagi para pelancong yang berkunjung di Kota Surakarta.

\section{Intip Solo}

Dalam istilah bahasa Jawa, intip adalah sebutan untuk kerak nasi. Di Kota
Surakarta, kerak nasi alias Intip ini diolah menjadi makanan cemilan khas yang renyah dan gurih. Intip merupakan hasil dari kerak endapan Nasi Liwet dari dasar periuk yang di masak dengan kayu bakar. Salah satu ciri khasnya yakni taburan kinco atau gula Jawa (gula merah) cair di atas gorengan atau taburan garam halus jika ingin rasanya asin. Intip Solo terbagi atas dua jenis yaitu intip asli dan Intip buatan.

Intip buatan sering ditemui di toko oleh-oleh Intip Pringgading Jalan Kusumayudan, Banjarsari Surakarta atau di sekitar Pasar Jongke Pajang, Laweyan Surakarta, toko oleh-oleh Pasar Singosaren Jalan Kalilarangan No.71 Kemlayan Serengan Surakarta serta terdapat pula di depan toko roti Orion Jalan Urip Sumoharjo No.80 Jebres, Surakarta. Harga Intip buatan ini $\mathrm{Rp} \mathrm{7.500/buah} \mathrm{dengan}$ kemasan 300 gram dengan pilihan rasa asin dan manis, sedangkan Intip yang asli seharga Rp 10.000.

m. Kue Serabi Solo

Kue Serabi Solo sebenarnya adalah semacam pancake yang berbentuk bulat seperti piring dengan sedikit kerak di sekelilingnya. Teksturnya kenyal namun tetap lembut, dan rasanya sangat legit. Berbeda dengan Kue Surabi Bandung yang menggunakan bahan dasar tepung terigu dan disiram dengan kuah gula kelapa cair, sedangkan Serabi Solo ini dihidangkan tanpa kuah manis. Cara pembuatannya masih tradisional dengan memasak adonan Serabi yang terdiri dari tepung beras, santan, gula, garam, dan daun pandan sebagai pewangi, kemudian adonan dimasak menggunakan wajan waja kecil yang dipanaskan dengan tungku arang selama kurang lebih tiga menit. Setelah matang Serabi digulung dengan daun pisang agar mudah ketika dimakan. Serabi 
Solo tersedia dalam beberapa varian rasa, seperti rasa original, coklat dan nangka.

Penjual kue Serabi Solo yang paling terkenal ialah Serabi Notosuman. Serabi Notosuman tersebut didirikan pertama kali pada tahun 1923 oleh pasangan suami istri Hoo Geng Hok dan Tan Giok Lan. Awalnya mereka sering mendapat pesanan membuat kue apem yang telah dimodifikasi bahan-bahan serta proses pembuatannya, lama-kelamaan banyak yang tertarik untuk memesan kue tersebut, yang kemudian berkembang usaha pembuatan kue Serabi Solo ini.

Penjual Serabi yang terkenal di daerah Notosuman ini ialah Serabi Nyonya Lidia yang beralamatkan di Jalan Moh. Yamin No.28 dan Serabi Nyonya Handayani dengan alamat Jalan Moh. Yamin No. 49 Serengan Surakarta. Adapun harga tiap kotak berisi sepuluh Serabi seharga 20.000 rupiah.

\section{n.Tahok}

Kuliner yang satu ini merupakan kuliner tradisional Cina yang dibawa oleh pendatang dari Tionghoa yang tinggal di Pasar Gedhe dan kemudian diturunkan dari generasi ke generasi hingga saat ini. Tahok berasal dari dua kata, yaitu tao atau teu yang berarti kacang kedelai, dan hoa atau hu yang berarti lumat. Berdasarkan etimologinya, bisa ditangkap bahwa Tahok adalah makanan dari kedelai yang dilumatkan. Sebenarnya makanan ini tidak jauh berbeda dengan tahu, namun teksturnya lebih lembut dengan warna putih bersih. Tekstur Tahok sangat lembut seperti adonan puding. Tahok dalam penghidangannya disiram dengan kuah dengan bahan dasar gula merah, daun sereh, daun pandan, dan jahe.

Tahok dengan bahan kuah seperti itu terasa sangat cocok sebagai menu penghangat badan. Selain sebagai penghangat badan, ternyata Tahok mempunyai segudang manfaat lainnya, misalnya saja sebagai sumber kalsium sehingga dapat memperkuat tulang dan mencegah osteoporosis; karena kandungan senyawa yang menyerupai estrogen Tahok juga dapat menunda datangnya menopouse dan mencegah kanker prostat bagi kaum laki-laki. Jika dikonsumsi setiap pagi secara rutin, Tahok juga dapat menurunkan kadar kolesterol dalam darah. Menu ini juga cocok sebagai menu untuk diet karena dapat menurunkan berat badan dan mengurangi obesitas.

Makanan ini dapat dijumpai di sebelah utara Kretek Gantung, Loji Wetan dan di Pasar Gedhe. Namun dari beberapa penjual tahok, yang paling terkenal ialah Tahok Pak Citro yang ada di sebelah selatan Pasar Gedhe Jebres Surakarta. Selain itu terdapat pula penjual Tahok yang cukup terkenal yaitu Tahok pak Slamet yang berada di Jalan Kapten Mulyadi No.76 Ketandan Jebres Surakarta, tepatnya di sebelah barat Loji Wetan. Penjual Tahok ini biasanya mulai buka dari pukul 06.00-16.00 WIB, dengan harga 4.000 rupiah per mangkok.

\section{o. Es Dawet Ayu Telasih}

Es Dawet Ayu Telasih ini berbeda dengan Es Dawet lainnya. Es Dawet ini terdiri dari onggok (semacam bubur dari tepung beras), ketan hitam, dan biji Telasih. Perbedaan antara Es Dawet Ayu Telasih dan Es Dawet dari Banjarnegara terletak pada sirup pemanisnya, jika dawet Banjarnegara menggunakan gula merah cair, sedangkan Es Dawet Telasih menggunakan sirup dari gula kelapa yang berwarna bening. Penjual Es Dawet Ayu Telasih yang paling terkenal ialah Es Dawet 
Bu Dermi yang berada di dalam Pasar Gedhe Solo, tepatnya di sekitar pintu masuk pasar sebelah utara. Satu mangkok Es Dawet dengan komposisi komplit seharga 5.000 rupiah.

\section{p. Wedang Dongo}

Wedang Dongo ialah salah satu minuman khas Kota Surakarta. Wedang Dongo sebenarnya tidak jauh berbeda dengan Wedang Ronde. Wedang Dongo dalam satu porsi dapat ditemukan racikan kacang, kolang-kaling, dan ronde (bulatan ketan berisi kacang halus yang ditumbuk). Namun bedanya, kuah Wedang Dongo berwarna lebih coklat dengan rasa jahe yang lebih kuat daripada Wedang Ronde. Wedang Dongo dapat ditemukan di Jalan Teuku Umar, Keprabon, Banjarsari. Tepatnya di sebelah tenggara Puri Mangkunegaran. Tempat ini buka dari jam 17.00 hingga pukul $23.00 \mathrm{WIB}$, dengan harga satu porsi 7.000 rupiah.

\section{Pemetaan Potensi Wisata Kuliner Kota Surakarta}

Berdasarkan hasil pengamatan serta pengumpulan data, maka dapat digambarkan sebaran tempat-tempat tujuan wisata kuliner berdasarkan lima kecamatan di Kota Surakarta. Lebih jelasnya digambarkan dalam tabel 1 (terlampir).

Seperti yang tertera dalam daftar Tabel 1 sebaran wisata kuliner di Kota Surakarta, bahwa kecamatan Banjarsari memiliki dua belas tempat wisata kuliner khas Kota Surakarta, yaitu: Gudeg Ceker Bu Kasno, Gudeg Ayu Gadjah Mada, Tengkleng Kambing Bu Joko Dlidir, Nasi Liwet Bu Wongso Lemu, Timlo Maestro, Sate Buntel Tambak Segaran, Sate Buntel Mbok Galak, Pecel Ndeso Restoran Pecel Solo, Pecel Ndeso Shleter Manahan, Selat
Solo Vien's, Wedang Dongo Keprabon, dan Intip Solo di Pusat Oleh-oleh Intip Pringgading Solo.

Selanjutnya Kecamatan Serengan memiliki tujuh tempat destinasi wisata kuliner, antara lain: Bestik Harjo, Tengkleng Kambing Bu Edi Pasar Klewer, Selat Solo Mbak Lies, Selat Solo Restoran Kusuma Sari, Serabi Notosuman Nyonya Lidia dan Nyonya Handayani, dan Pusat Oleh-oleh Intip Singosaren.

Berikutnya Kecamatan Jebres memiliki tujuh tempat tujuan wisata kuliner seperti: Tengkleng Kambing Pasar Gedhe, Restoran Timlo Solo, Warung Timlo Sastro, Pusat Oleh-oleh Intip di Roti Orion, Pecel Ndeso Pasar Gedhe, Tahok dan Es Dawet Ayu Telasih Pasar Gedhe.

Kecamatan Laweyan memiliki enam tempat tujuan wisata kuliner yaitu Gudeg Ceker Restoran Adem Ayem, Gudeg Ceker Rumah Makan Gudeg Ayu Kota Barat, Bestik Pak Darmo, Intip Solo Pasar Jongke, Sate Kere Yu Rebi dan Bestik Pak Mangun. Sementara itu, Kecamatan Pasar Kliwon memiliki tiga tempat wisata kuliner yaitu: Sate Buntel Haji Bejo, Sate Buntel Pak Narto dan Soto Gading.

Berdasarkan data mengenai sebaran wisata kuliner pada tiap-tiap kecamatan di Kota Surakarta, maka dibuat peta wisata kuliner di Kota Surakarta sebagaimana terlampir.

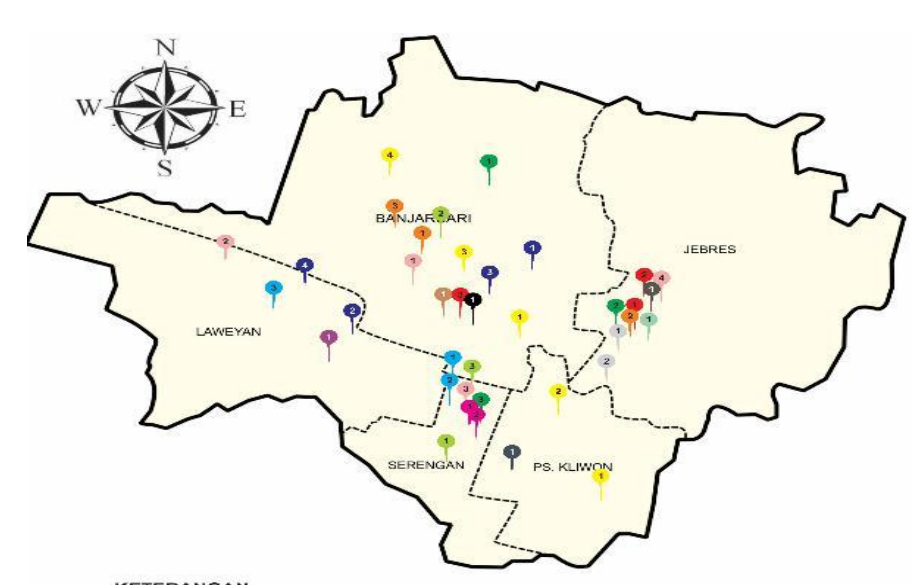

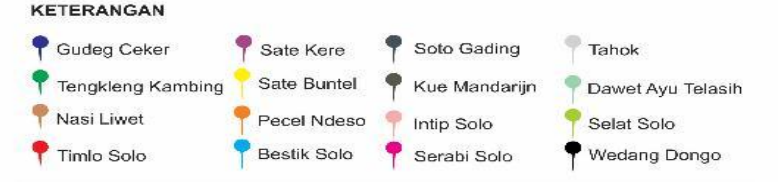




\section{Gambar 1. Peta Wisata Kuliner Kota Surakarta Sumber: Diolah oleh Peneliti, 2017}

\section{Kesimpulan}

Potensi kuliner khas Kota Surakarta yang tersebar di seputaran kota sungguh beragam dan menarik seperti misalnya di Kecamatan Banjarsari memiliki dua belas tempat wisata kuliner khas Kota Surakarta, yaitu: Gudeg Ceker Bu Kasno, Gudeg Ayu Gadjah Mada, Tengkleng Kambing Bu Joko Dlidir, Nasi Liwet Bu Wongso Lemu, Timlo Maestro, Sate Buntel Tambak Segaran, Sate Buntel Mbok Galak, Pecel Ndeso Restoran Pecel Solo, Pecel Ndeso Shelter Manahan, Selat Solo Vien's, Wedang Dongo Keprabon, dan Intip Solo di Pusat Oleh-oleh Intip Pringgading Solo. Selanjutnya Kecamatan Serengan memiliki tujuh tempat destinasi wisata kuliner, antara lain: Bestik Harjo, Tengkleng Kambing Bu Edi Pasar Klewer, Selat Solo Mbak Lies, Selat Solo Restoran Kusuma Sari, Serabi Notosuman Nyonya Lidia dan Nyonya Handayani, dan Pusat Oleh-oleh Intip Singosaren. Berikutnya Kecamatan Jebres memiliki tujuh tempat tujuan wisata kuliner seperti: Tengkleng Kambing Pasar Gedhe, Restoran Timlo Solo, Warung Timlo Sastro, Pusat Oleh-oleh Intip di Roti Orion, Pecel Ndeso Pasar Gedhe, Tahok dan Es Dawet Ayu Telasih Pasar Gedhe. Kecamatan Laweyan memiliki enam tempat tujuan wisata kuliner yaitu Gudeg Ceker Restoran Adem Ayem, Gudeg Ceker Rumah Makan Gudeg Ayu Kota Barat, Bestik Pak Darmo, Intip Solo Pasar Jongke, Sate Kere Yu Rebi dan Bestik Pak Mangun.
Sedangkan Kecamatan Pasar Kliwon memiliki tiga tempat wisata kuliner yaitu: Sate Buntel Haji Bejo, Sate Buntel Pak Narto dan Soto Gading. Melihat beragamnya potensi yang dimiliki oleh Kota Surakarta berpeluang besar untuk dikembangkan sebagai kota destinasi wisata kuliner sehingga mampu menarik minat wisatawan berkunjung di Kota Surakarta.

\section{Daftar Pustaka}

Bappeda Kota Surakarta. 2015. Profil Daerah Kota Surakarta. Surakarta.

Baskoro, Ardi. 2012. Kuliner di Keraton Surakarta (Kesinambungan dan perubahannya). (Tesis). Program Studi Kajian Budaya, Program Pasca Sarjana Universitas Sebelas Maret Surakarta.

BPS Kota Surakarta. 2016. Data Surakarta Dalam Angka tahun 2015. Surakarta.

Data Research Group Pariwisata dan Budaya DIII Usaha Perjalanan Wisata FIB UNS tentang peta lokasi kuliner di Surakarta.

Echols, John M. dan Shadily, Hasan. 1993. Kamus Inggris-Indonesia. Jakarta: PT. Gramedia Pustaka Utama.

Kesrul, M. 2003. Penyelenggaraan Operasi Perjalanan Wisata. Jakarta. PT. Grasindo.

Miles dan Huberman.1992. Analisis Data Kualitatif. (penerjemah: Tjetjep Rohendi Rohidi). Jakarta: UI press.

Munasef, 1996. Manajemen Usaha Pariwisata di Indonesia. Jakarta. PT Toko Gunung Agung.

Nasution, S. 1996. Berbagai Pendekatan Dalam Proses Belajar dan Mengajar. Jakarta: Bumi Aksara.

Rahman, Fadly. 2011. Rijsttafel Budaya Kuliner Di Indonesia Masa Kolonial 
Tahun 1870-1942. Jakarta: PT Gramedia Pustaka Utama.

Stowe and Johnston. 2008. The Food Culture Roadtrip: Experiental Learning in Spain. New Orlean: University of Calgary.

Suratman, Darsiti. 2001. Kehidupan Dunia Keraton Surakarta. Yogyakarta: YUI

Suriani, Ni Made. 2009. Seni Kuliner Bali sebagai Salah Satu Daya Tarik Wisata Studi Kasus di Warung Babi Guling Ibu Oka di Kelurahan Ubud, Gianyar, Bali. Program Studi Magister S2 Kajian Pariwisata. (Tesis). Denpasar: Universitas Udayana.

Sutirto, Tundjung Wahadi, dkk. 1995. Analisis Potensi Pariwisata di Kotamadya Surakarta. Surakarta: Lembaga Penelitian UNS.
Sutopo, H.B.. 1982. Pengumpulan Data dan Analisis Penelitian Kualitatif. Surakarta: Lembaga Penelitian UNS.

Suwantoro, Gamal. 2004. Dasar-Dasar Pariwisata. Yogyakarta: PT Gramedia.

Yuliati, Umi dan Hastuti, Tiwuk Kusuma. 2007. Strategi Pengembangan Pariwisata di Surakarta Pada Awal abad XX. Laporan Penelitian Dipa LPPM UNS 2007. Program Studi Diploma III Usaha Perjalanan Wisata Universitas Sebelas Maret Surakarta. 


\section{Lampiran}

Tabel 4. Daftar menu As Per Chef

Tabel 1

Sebaran Potensi Obyek Wisata Kuliner Kota Surakarta

\begin{tabular}{|c|c|c|c|c|c|c|}
\hline \multirow{2}{*}{ No } & \multirow{2}{*}{ Nama Kuliner } & \multicolumn{5}{|c|}{ Kecamatan } \\
\hline & & Banjarsari & Laweyan & Serengan & Ps. Kliwon & Jebres \\
\hline 1 & Gudeg Ceker & V & V & & & \\
\hline 2 & Tengkleng Kambing & $\sqrt{V}$ & & $\sqrt{ }$ & & 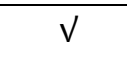 \\
\hline 3 & Nasi Liwet & $\sqrt{V}$ & & & & \\
\hline 4 & Timlo & $\sqrt{V}$ & & & & 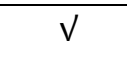 \\
\hline 5 & Sate Kere & $\sqrt{V}$ & & & & \\
\hline 6 & Sate Buntel & $\sqrt{V}$ & & & $\sqrt{ }$ & \\
\hline 7 & Pecel Ndeso & $\sqrt{V}$ & & & & 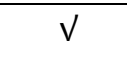 \\
\hline 8 & Bestik Solo & & V & $\sqrt{V}$ & & \\
\hline 9 & Selat Solo & $\mathrm{V}$ & & 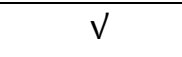 & & \\
\hline 10 & Soto Gading & & & & $\mathrm{V}$ & \\
\hline 11 & Kue Mandarijn & & & & & 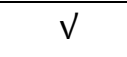 \\
\hline 12 & Intip & $\mathrm{V}$ & $\sqrt{ }$ & $\sqrt{ }$ & & $\mathrm{V}$ \\
\hline 13 & Serabi Notosuman & & & $\mathrm{V}$ & & \\
\hline 14 & Tahok & & & & & 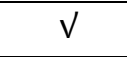 \\
\hline 15 & Dawet Ayu Telasih & & & & & $v$ \\
\hline 16 & Wedang Dongo & $\mathrm{V}$ & & & & \\
\hline
\end{tabular}

